\title{
Discriminating Complainers and Non-Complainers: A Study within the Malaysian Context
}

\author{
AIZZAT MOHD. NASURDIN \\ OSMAN MOHAMED \\ T. RAMAYAH \\ SHISHI KUMAR PIARALAL \\ School of Management \\ Universiti Sains Malaysia
}

\begin{abstract}
The purpose of this study is to examine whether consumers' complaint behavior varies according to demographics, psychographics, and attitude toward businesses as well as product attributes. Discriminant analysis on a sample of 122 consumers residing in north Malaysia showed that complainers were males, married, better educated, and holding white collar jobs. Complainers were found to be more confident, more assertive, individualistic, and possessed a positive attitude toward complaining. Consumers who have a more positive attitude towards businesses and product attributes were more likely to complain. The discriminant model was able to predict behavior of complainers better than chance. Implications and suggestions for future research are discussed.
\end{abstract}

\begin{abstract}
ABSTRAK
Tujuan kajian ini adalah untuk mengkaji sama ada gelagat mengadu di kalangan pengguna adalah berbeza berdasarkan unsur demografi, elemen psikografi, sikap terhadap perniagaan dan atribut produk. Analisis diskriminan terhadap sampel yang terdiri daripada 122 pengguna di Utara Semenanjung Malaysia menunjukkan golongan lelaki, golongan yang sudah berkahwin, golongan yang berpendidikan tinggi dan mereka mempunyai pekerjaan kolar putih lebih suka membuat aduan. Pengadu juga didapati lebih berkeyakinan, lebih tegas, bersikap individualistik, serta mempunyai sikap yang lebih positif terhadap tindakan mengadu. Pengguna yang mempunyai sikap positif terhadap perniagaan dan atribut produk didapati lebih cenderung untuk membuat aduan. Model diskriminan yang dibentuk berupaya meramal gelagat mengadu lebih baik daripada nasib. Implikasi dan cadangan untuk penyelidikan selanjutnya dibincangkan.
\end{abstract}

\section{INTRODUCTION}

Consumer dissatisfaction and consumer complaint behaviors have grown in importance over the last few decades. This is especially true for developed Western countries where consumerism activity is an accepted phenomenon (Kaynak,
Kucukemeriroglu, \& Odabasi, 1992). To be successful in a competitive business environment, producing firms and sellers need to understand and satisfy the needs of their customers. Marketers must realize that their survival depends on the goodwill of their customers (Keng, Richmond, \& Han, 1995). If customer complaints are not handled properly, the consequences will be far 
reaching. This is because dissatisfied customers will not only give up patronage, but are also bound to convey a negative message, jeopardizing a company's image (Lewis, 1983). According to Kim, Kim, Im, and Shin (2003), dissatisfied customers communicate about their negative experiences with an average of nine other persons. Given the potentially serious repercussions on an organization resulting from the spread of negative word-of-mouth messages, understanding customer complaint behavior becomes critical. In this regard, marketers should ensure customer satisfaction and rectify any dissatisfaction concerning a product or service. One way to do so is via customer service. Complaint handling of a dissatisfied complainer is one form of customer service. If the complaint of a dissatisfied customer was handled successfully such that the dissatisfied customer could be turned into a satisfied customer, then the possibility of customer retention would be high. In additional, the producing firm or seller will gain free advertising through positive wordof- mouth from these satisfied customers. Thus, firms that are renowed for consistently remedying customer complaints are more likely to foster customer loyalty, and over time, may increase their market share. Conversely, firms that have developed a reputation for their unwillingness to entertain their customers' complaints are more likely to lose their customers.

Numerous studies on complaint behavior have been undertaken in the United States (e.g. Richins, 1981; Beardon \& Teel, 1983; Morganosky \& Buckley, 1986; Bettina, Alan, \& Emin, 1991; Kolodinsky, 1993; Blodgett, Wakefield, \& Barnes, 1995; Nyer, 2000). In developed markets like the United States, consumer complaints are handled with care. In addition, products bought can be exchanged or returned within a stipulated time period if consumers are not satisfied with the products (Phau \& Sari, 2004). This is not the case for many developing countries. Furthermore, there is a paucity of research on this subject within the Asian context. To date, only two studies concerning complaint behavior have been undertaken in South-East Asia. The first study conducted by Keng et al. (1995) attempts to profile complaint behavior of Singaporean consumers. A very recent study carried out by Phau and Sari (2004) attempts to investigate why some people tend to complain while others do not among Indonesian consumers. The findings from these two studies seem to indicate some similarities in terms of the profile of complainers. For example, consumers who are educated and earned high incomes are likely to complain.

Today, Malaysian consumers are more aware of their rights. The establishment of the Federation of Malaysian Consumers Association (FOMCA) in 1973 is a reflection of the nation's commitment to consumer protection (http:// www.fomca.org.my). This non-profit body aspires to promote an organized consumer movement in Malaysia. With its 12 affiliates comprising of various state consumer associations as well as 4 non-affiliates, FOMCA aims at enhancing the rights of consumers that would subsequently lead to a better quality of life. The increasing awareness about their rights and consumerism among Malaysian cousumers is indicated by the rising number of complaints made by consumers over the past three decades. For example, in 1972, the number of complaints received by the Consumer Association of Penang (CAP), a nonaffiliate of the Federation of Malaysian Consumers Associations was only 55 (CAP, 1994). This relatively poor response may be due to the fact that a majority of Malaysian consumers prefer to take private actions such as boycotting the brand, switching brands and/or sellers and spreading negative word-of-mouth to their family members, friends and other potential consumers, rather than file a complaint against the producing firm or seller. According to the CAP, Malaysian consumers are more likely to be fatalistic when they have a dissatisfying experience with a product by blaming themselves rather than the manufacturer (CAP, 1994). Nevertheless, the Public Complaints Bureau (PCB) recorded a total of 20,000 complaints in 2000 whereas CAP receives over 3,000 complaints a year (Vijian, 2001). Hence, this article intends to explore and understand complaint behavior among Malaysian consumers. Therefore, the objective of this study is to examine whether consumers' complaint behavior varies according to demographical, psychographical and attitudinal factors. 


\section{LITERATURE REVIEW}

\section{Consumer Complaint Behavior}

Dissatisfaction caused by negative disconfirmation of purchase expectations is recognized as a primary determinant of legitimate consumer complaint behavior (Oliver, 1980; Williams, Drake, \& Moran, 1993). Dissatisfaction occurs if product performance, expressed in terms of attributes/outcome evaluations, is below anticipated levels (Keng et al., 1995). Dissatisfied customers may subsequently engage in complaint behavior. According to Day and Landon (1977), complaint behavior engaged by consumers as a result of their dissatisfaction is based on whether the responses are of a public or private nature. The complaint process as conceptualized by Day and Landon (1977) is presented in Figure 1.

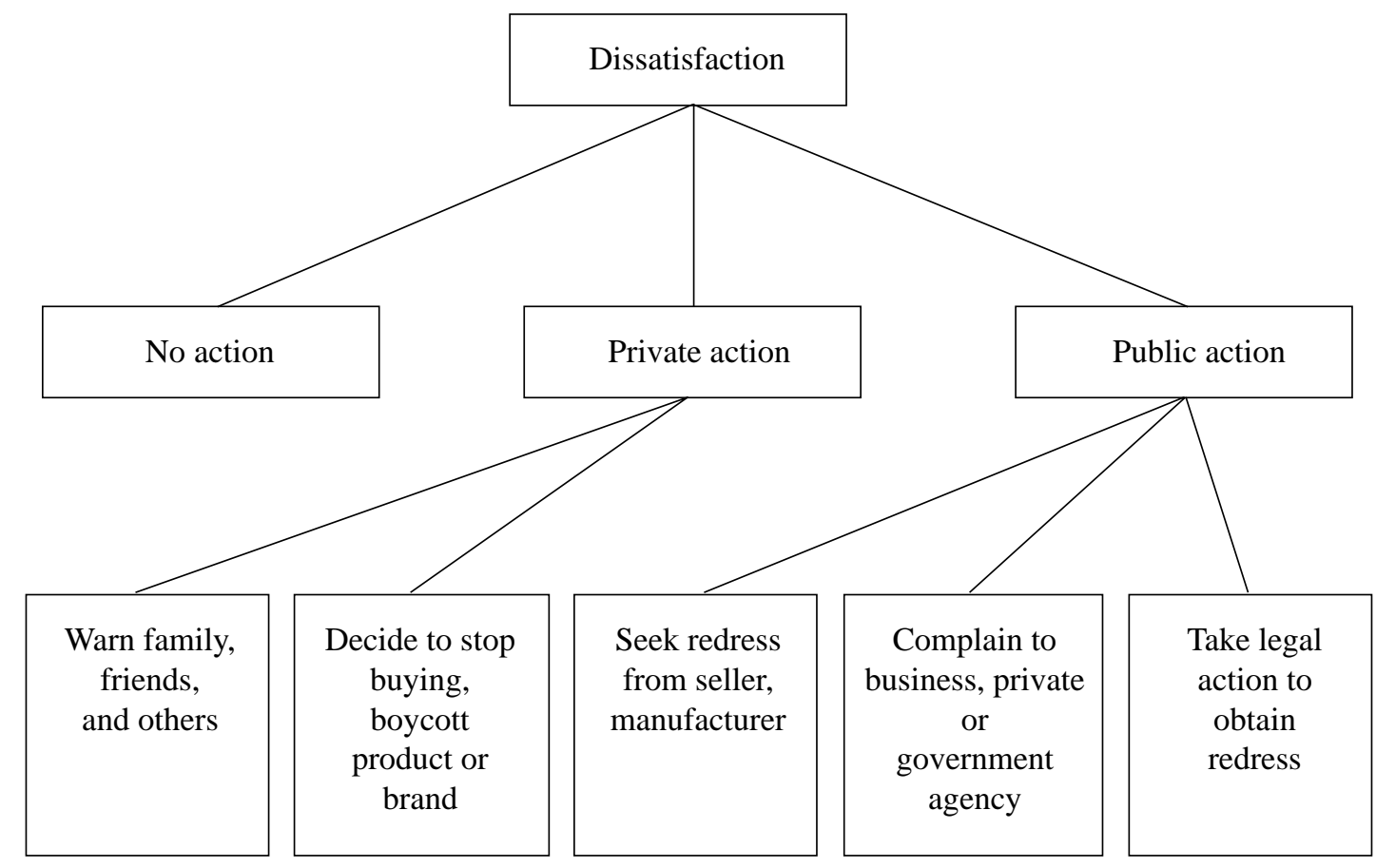

Figure 1

Consumer complaint behavior

As shown in Figure 1, consumers may opt for a number of alternative courses of action, namely "no action", "private action", and "public action". A dissatisfied consumer who does not react in any manner and continues to behave normally towards a product is described as taking "no action". Private actions include decisions to stop further purchases (boycott the product or brand) and warnings to friends, family and others through negative word-of-mouth. Public actions, on the other hand, include seeking redress from the seller or manufacturing firm, and filing complaints to a third party consumer affairs institution (Day \& Landon, 1977; Bearden \& Teel, 1983). Hirschman (1970) found that firms' reactions to consumers' dissatisfaction varies significantly depending upon the nature of the industry involved. According to past scholars (for example, Hirschman, 1970; Singh, 1990), consumers are less likely to take public actions and more likely to take private 
actions against industries characterized as loose monopolies. One such industry relates to durable products.

\section{The Impact of Demographics on Complaint Behavior}

Demographic variables have been found to influence the different types of complaint behavior. For instance, a study by Bettina et al. (1991) found that the Mexican-American male consumers make most of the financial decisions. This finding suggests that the male head of a household may be more likely to initiate the complaint process. Subsequently, in Kolodinsky (1993)'s study which examined public complaint actions, company responses and subsequent purchases within the medical industry, which has been categorized as a loose monopoly, it was found that women and elderly consumers were more likely to use private actions rather than public actions. Keng et al. (1995) found that females rather than males prefer to complain by using public actions rather than private actions. Although no significant differences were found between complaint behavior and marital status in Keng et al. (1995) study, it can be proposed that in Malaysia, married consumers particularly those with many children are more inclined to complain.

This is because married couples with many dependents are more likely to maximize value for money spent on increased family commitments. As such, they are quick to identify defects for products purchased. This proposition is further supported by the findings of Hansen and Woolridge (2002). In their investigation of complaint behavior among church members, Hansen and Woolridge (2002) discovered that groups consisting of married members with the least number of children were most satisfied with their church experience and demonstrated no inclination to complain.

Young, better educated and higher income consumers prefer to complain publicly (Warland, Herman, \& Willits, 1975; Day \& Landon, 1977). According to Beardon and Mason (1984), consumer complaint behavior is inversely related to age and positively linked to income and education. Moyer (1985) contended that consumers with higher income, who were better educated, had professional jobs, and were younger were more likely to complain. Other studies (e.g. Morganosky \& Buckley,1986; Singh, 1990) also found similer relationship between complaint behaviour and age, income, education, and occupation. A recent study by Phau and Sari (2004) demonstrated that complainers in Indonesia too had a higher level of income and education. Keng et al. (1995), on the other hand, found that complainers who resort to public actions were older. Ethnicity is another important influence on consumer complaint behavior. Cicarelli (1974) in investigating the behavior of black and white consumers in the United States found differences in their consumption patterns. Bettina et al. (1991) also discovered differences between MexicanAmerican and the general population of the United States in terms of complaint behavior. Watkins and Liu (1996) found that differences in consumers' behavioral responses to post purchase dissatisfaction were strongly influenced by their culture.

\section{The Impact of Psychographics on Complaint Behavior}

Psychographic variables include one's opinions and aspects of personality (e.g. self-confidence, individualism, conservatism, assertiveness, risktaking orientation, and sense of justice). These variables have been found to influence consumers' complaint behavior. Allison (1978) discovered that individuals who were more assertive, possessed self-confidence, and were self-monitors, were more likely to complain. Similarly, consumers who were individualistic in nature were more inclined to be complainants (Morganosky \& Buckley, 1986). According to Morganosky and Buckley (1986), complainants valued uniqueness and individuality, and had a greater sense of independence compared to non-complainants. Bearden and Mason (1984) found that complaint behavior had a direct relationship with assertiveness but an indirect one with feelings of powerlessness. In additional one's attitude toward complaining would influence whether the person would resort to actual complaint behavior. Attitude towards complaining refers to an individual's 
disposition to seek redress when dissatisfied with a product (Richins, 1987). According to Richins (1981), there are three dimensions of attitudes: (1) the perception of societal benefits likely to result from complaining, (2) whether complaining is worth the trouble, and (3) the individual's norms concerning complaining. Richins (1981) contended that there were positive relationships between these dimensions of attitudes and actual complaint behavior. In another study, Beardon and Teel (1983) discovered that attitude had a significant relationship with intention to complain. Dissatisfied consumers who had a positive attitude toward complaining were more inclined to use public actions instead of private ones (Blodgett et al., 1995; Keng et al., 1995; Phau \& Sari, 2004).

\section{The Impact of Attitude toward Business on Complaint Behavior}

Consumers' attitudes towards businesses have an influence on their complaint behavior. Factors such as seller's reputation for quality and service, responsiveness of manufacturers and retailers to complaints, and the amount of sales pressure exerted by the seller have been found to be related to the lodging of complaints (e.g. Day \& Landon, 1977; Folkes, Koletsky \& Graham, 1987; Singh, 1990; Kolodinsky, 1993; Keng et al., 1995). According to Folkes et al. (1987), when a consumer perceived that the existence of a problem concerning a product or service lied within the control of the seller, there was a strong likelihood that the consumer would complain using public actions. Singh (1990) noted that private actions were less common when the sellers or manufacturing firms were perceived as responsive to consumer complaints. In addition, the probability of consumers complaining using public actions was higher for large companies and those that offered guarantees or warranties (Kolodinsky, 1995).

\section{The Impact of Product Attributes on Complaint Behavior}

Product attributes or product importance refers to the relative "worth" that an individual places on a particular product (Bloch \& Richin, 1983). Durable products are considered to be more important than non-durables because they are relatively more expensive, and consumers rely heavily on the product and derive greater enjoyment from using it. When the worth of a product is perceived to be higher, consumers tend to opt for more public actions when complaining (Oster, 1980; Blodgett et al., 1995). Similarly, consumers are less likely to complain under low harm failure conditions whilst redress seeking is more likely to occur under high harm failure conditions (Richins 1983,1987). In addition, Keng et al. (1995) discovered that consumers tended to complain using public actions when the price of the product was high. According to Keng et al. (1995), if the product was defective and socially visible, then the probability of filing a complaint was higher. Tax, Brown, and Chandrashekaran (1998) found that most complaints resulted from problems judged by the consumers to be highly important.

\section{THEORETICAL FRAMEWORK AND HYPOTHESES}

This study adopted Keng et al. (1995) theoretical framework, as shown in Figure 2.

Four major hypotheses were developed as follows:

H1: Consumer complaint behavior differs according to demographics.

H1a: Consumer complaint behavior differs according to gender.

H1b: Consumer complaint behavior differs according to age groups.

H1c: Consumer complaint behavior differs according to education level.

H1d: Consumer complaint behavior differs according to ethnic groups.

H1e: Consumer complaint behavior differs according to marital status.

H1f: Consumer complaint behavior differs according to job categories. 
H1g: Consumer complaint behavior differs according to income groups.

H2: Consumer complaint behavior differs according to psychographics.

H2a: Consumer complaint behavior differs according to assertiveness level.

H2b: Consumer complaint behavior differs according to conservatism level.

H2c: Consumer complaint behavior differs according to individualism level.
H2d: Consumer complaint behavior differs according to attitude towards complaining.

H2e: Consumer complaint behavior differs according to risk-taking attitude.

H2f: Consumer complaint behavior differs according to sense of justice.

H3: Consumer complaint behavior differs according to attitudes toward businesses.

H4: Consumer complaint behavior differs according to consumers' views on product attributes.

\section{Demographics}

Gender, marital status, income, age, education, job, and ethnicity

\section{Psychographics}

Assertiveness, self-confidence \& individualism, conservatism, risktaking attitude, attitude toward complaining and sense of justice

\section{Attitudes toward} businesses

Consumers' attitudes towards business practices

\section{Product attributes}

Consumers' view towards product attributes in terms of price, usage, etc.

Figure 2

Research framework 


\section{METHODOLOGY}

\section{Sampling Procedure}

Consumers in this study consisted of employees working in manufacturing organizations located in the states of Penang and Kedah. A total of 350 questionnaires were distributed via personal contacts and electronic mails. Respondents were given two weeks to complete and return the questionnaires. A total of 183 questionnaires were received representing a response rate of $52.3 \%$. However, only 122 questionnaires were included in the statistical analyses.

\section{Measurement}

The items designed to measure the study variables were adopted from Keng et al. (1995). The full questionaire give consisted of 41 items with a total of 27 items relating to constructs such as attitudes toward complaining, risk taking attitude, assertiveness, self-confidence and individualism, conservatism, and sense of justice were utilized. A 5-point response format ranging from (1) "strongly disagree" to (5) "strongly agree" was used. The 27 items can be divided into selfconfidence and individualism (6 items), conservatism (5 items), risk taking attitude (4 items), attitudes towards complaining (4 items) and sense of justise ( 3 items). Another ten items were utilized to measure the respondent's opinion about business practices and the perception of business responsiveness. Four items were used to measure the respondent's perception of product attributes.

The dependent variable in this study is consumer complaint behavior which can be divided into two in accordance to Keng et al. (1995) namely: (1) complainers - taking public actions such as filing a complaint toward the manufacturer or seller, or filing a formal complaint with a third party other than the manufacturer or seller, such as (CAP) and initiating legal action, and (2) non-complainers taking private actions which involve exit behavior and spreading negative word-of-mouth to family members, friends and relatives. Not taking any action when there is dissatisfaction with a product (no action) is also considered as private action.
To gauge a respondent's response towards a product that he/she is dissatisfied with, 5 questions were utilized. The first question examines the types of possible actions that respondents would pursue if they encountered an unsatisfactory purchase (for instance, switching brand, stop buying, inform family, and others). A 4-point response format was used ranging from (1) "Very unlikely to (4) "Very likely". Using a "Yes" or "No' answer format, the second question, asks respondents to recall if they had encountered any unsatisfactory product (durable product) for the last 12 months. Those who have purchased a product that created dissatisfaction will have to name the product in the third question (such as electrical, clothing, automobile, and others) and state price in the fourth question. Question 5 identifies the possible public and private actions according to the taxonomy of complaint actions developed by Day and Landon (1977). It asks the respondent to indicate at least one or more actions that were taken in response to a complaint. This question was determine whether the respondent is a complainer or non-complainer.

In this study, a dissatisfied consumer can opt for two types of action, namely public and private. Public actions are taken when consumers choose to react on their dissatisfaction by seeking redress through voice actions and third party actions. Voice actions involve complaining directly to the sellers and manufacturers. Third party actions involve complaining through the various consumer associations, writing to the press, and taking legal actions if their voice actions failed to satisfy them. Private actions, on the other hand, are taken when consumers choose to react on their dissatisfaction with a product by warning family members, friends and others via negative word-of-mouth as well as boycotting the product or brand. Whereas, 'no action' or 'did nothing' is considered as part of private actions. Complainers in this study refer to consumers who chose public actions when they were dissatisfied with a product, whereas non-complainers are those who chose not to take any action or taking only private actions when they were dissatisfied with a product. Demographic information of respondents relating to gender, marital status, race, age, education level, monthly income, and occupation as also gathered. 
Table 1

Profile of Respondents

\begin{tabular}{|c|c|c|c|}
\hline Variable & Category & Frequency & Percent \\
\hline \multirow[t]{2}{*}{ Gender } & Male & 67 & 54.9 \\
\hline & Female & 55 & 45.1 \\
\hline Marital & Single & 33 & 27.0 \\
\hline Status & Married & 89 & 73.0 \\
\hline \multirow[t]{4}{*}{ Ethnicity } & Malay & 52 & 42.6 \\
\hline & Chinese & 40 & 32.8 \\
\hline & Indian & 28 & 23.0 \\
\hline & Others & 2 & 1.6 \\
\hline \multirow[t]{4}{*}{ Age } & $15-24$ & 13 & 10.7 \\
\hline & $25-29$ & 24 & 19.7 \\
\hline & $30-34$ & 45 & 36.9 \\
\hline & $\geq 35$ & 40 & 32.8 \\
\hline \multirow[t]{4}{*}{ Education } & SRP & 1 & 0.8 \\
\hline & SPM/STPM & 22 & 18.0 \\
\hline & Cert/Diploma & 31 & 25.4 \\
\hline & $\geq$ Degree & 68 & 55.7 \\
\hline \multirow[t]{4}{*}{ Monthly Income } & $\geq \mathrm{RM} 1000$ & 11 & 9.0 \\
\hline & RM1001 - RM2500 & 51 & 41.8 \\
\hline & RM2501 - RM4000 & 37 & 30.3 \\
\hline & $\geq \mathrm{RM} 4001$ & 23 & 18.8 \\
\hline \multirow[t]{2}{*}{ Job Category } & White Collar & 45 & 36.9 \\
\hline & Blue Collar & 77 & 63.1 \\
\hline
\end{tabular}

\section{RESULTS}

Table 1 presents the demographic profile of respondents.

Table 1, shows that the sample consisted of more males $(54.9 \%)$ compared to females $(45.1 \%)$. The majority $(73 \%)$ of them were married. In terms of age, $32.8 \%$ were 35 years and above. Classification of the respondents by ethnicity shows that $42.6 \%$ were Malays, $32.8 \%$ were Chinese, $23.0 \%$ were Indians and $1.6 \%$ were others. Education-wise, the majority $(55.7 \%)$ of them had bachelor degrees and above. The majority $(36.9 \%)$ of the respondents sampled were white-collar workers. In terms of income, 50.8\% of the respondents had monthly incomes of RM2500 and below.

Table 2 indicates the 10 possible actions that consumers were likely to take when they were dissatisfied with a product. Table 2 also shows that $68 \%$ of the respondents preferred to tell their family, friends and others in the form of negative 
Table 2

Respondents' Actions toward Dissatisfied Products

\begin{tabular}{lcc}
\hline Variable & $\begin{array}{c}\text { Frequency of } \\
\text { "Yes" }(\boldsymbol{\%})\end{array}$ & $\begin{array}{c}\text { Frequency of } \\
\text { "No" (\%) }\end{array}$ \\
\hline Did nothing & $6(4.9)$ & $116(95.1)$ \\
Quit the product & $44(36.1)$ & $78(63.9)$ \\
Switch the brand & $60(49.2)$ & $62(50.8)$ \\
Stop buying from the seller & $43(35.2)$ & $79(64.8)$ \\
Told family, friends and others in form of & $83(68.0)$ & $39(32.0)$ \\
negative word-of-mouth & & \\
Told the seller and asked for remedy & $41(33.6)$ & $81(66.4)$ \\
Told the manufacturer and asked for redress & $18(14.8)$ & $104(85.2)$ \\
Told a third party or CAP & $2(1.6)$ & $120(98.4)$ \\
Took legal action & $0(0)$ & $122(100)$ \\
Wrote to the press & $2(1.6)$ & $120(98.4)$ \\
\hline
\end{tabular}

word-of-mouth. In addition, respondents preferred to switch brands (49.2\%), stopped buying the brand $(36.1 \%)$, and stopped buying from the same seller $(35.2 \%)$. Almost all $(95.1 \%)$ of the respondents sampled indicated that they were likely to take action and would not remain quiet when they were dissatisfied with a product. None of the respondents had taken legal action against the manufacturing company or seller associated with the dissatisfied product. A very small portion $(1.6 \%)$ of the respondents had taken the matter to the press and third parties to address their dissatisfaction.

Table 3 presents the categories of products with which consumers were dissatisfied. As shown in Table 3, of the 122 consumers sampled, the largest proportion (33.6\%) of their dissatisfaction involved electrical products, followed by clothing (27\%), and automobile (27\%).

Table 4 indicates the price of products with which consumers were dissatisfied. As shown in Table 4, of the 122 consumers sampled, the largest proportion (40.2\%) of their dissatisfaction lies with rather expensive products involving prices of RM500 and above.

\section{Reliability of Instruments}

Table 5 shows the reliability coefficients of the independent variables.As shown in Table 5, the reliabilities of the instruments used were considered acceptable since they are all above 0.6 (Nunnally \& Bernstein, 1994).

\section{Differences in Complaint Behavior According to Demographics between Complainers and Non-Complainers}

In testing the first hypothesis, the chi-square test was undertaken. Table 6 shows the chi-square test results for difference between complainers and non-complainers according to demographic variables.

As can be seen from Table 6, the variables that show significant differences were gender $(\mathrm{p}<0.05)$, marital status $(\mathrm{p}<0.1)$, educational level $(\mathrm{p}<0.01)$, and job category $(\mathrm{p}<0.05)$. No significant differences in complaint behavior were obtained for income level and ethnicity. These results provided evidence to support H1a, H1c, H1e, and H1f. Thus, H1 was partially supported. 
Table 3

Category of Dissatisfied Product

\begin{tabular}{lcc}
\hline Product category & Frequency & Percentage \\
\hline Electrical & 41 & 33.6 \\
Clothing & 33 & 27.0 \\
Automobile & 25 & 20.5 \\
Others & 23 & 18.9 \\
Total & 122 & \\
\hline
\end{tabular}

Table 4

Price of Dissatisfied Product

\begin{tabular}{lcc}
\hline Price of product & Frequency & Percentage \\
\hline Less than RM 50 & 20 & 16.4 \\
RM 50 - RM 99 & 16 & 13.1 \\
RM 100 - RM 299 & 20 & 16.4 \\
RM 300 - RM 499 & 17 & 13.9 \\
RM 500 and above & 49 & 40.2 \\
\hline
\end{tabular}

\section{Table 5}

Reliability Coefficients of the Independent Variables

Variable

Cronbach's Alpha

Self-confidence and individualism

0.64

Conservatism

0.63

Assertiveness

0.60

Risk taking attitude

0.62

Attitude toward complaining

0.62

Sense of justice

0.66

Attitude toward business

0.66

Product Attribute

0.76 
Table 6

Percentage Distribution of Complainers and Non-Complainers

\begin{tabular}{|c|c|c|c|c|c|}
\hline \multirow[t]{2}{*}{ Variable } & & \multicolumn{2}{|c|}{$\%$} & \multirow[t]{2}{*}{$\mathbf{N}$} & \multirow[t]{2}{*}{$\chi^{2}$} \\
\hline & & Complainers & $\begin{array}{l}\text { Non- } \\
\text { pplainers }\end{array}$ & & \\
\hline \multirow[t]{2}{*}{ Gender } & Male & 40.3 & 59.7 & 67 & \multirow[t]{2}{*}{$5.80^{* *}$} \\
\hline & Female & 20.0 & 80.0 & 55 & \\
\hline Marital & Single & 18.2 & 81.8 & 33 & $3.55^{*}$ \\
\hline Status & Married & 36.0 & 64.0 & 89 & \\
\hline \multirow[t]{4}{*}{ Ethnicity } & Malay & 30.8 & 69.2 & 52 & \multirow[t]{4}{*}{1.21} \\
\hline & Chinese & 30.0 & 70.0 & 40 & \\
\hline & Indian & 35.7 & 64.3 & 28 & \\
\hline & Others & 0.0 & 100.0 & 2 & \\
\hline \multirow[t]{4}{*}{ Age group (years) } & $15-24$ & 23.1 & 76.9 & 13 & \multirow[t]{4}{*}{2.54} \\
\hline & $25-29$ & 20.8 & 79.2 & 24 & \\
\hline & $30-34$ & 37.8 & 62.2 & 45 & \\
\hline & $\geq 35$ & 32.5 & 67.5 & 40 & \\
\hline Educational & SRP & 0.0 & 100.0 & 1 & \multirow[t]{4}{*}{$12.32^{* * *}$} \\
\hline \multirow[t]{3}{*}{ Level } & SPM/STPM & 4.5 & 95.5 & 22 & \\
\hline & Cert/Diploma & 25.8 & 74.5 & 31 & \\
\hline & $\geq$ Degree & 42.6 & 57.4 & 68 & \\
\hline \multirow[t]{4}{*}{ Monthly Income } & $\leq \mathrm{RM} 1000$ & 18.2 & 81.8 & 11 & \multirow[t]{4}{*}{4.21} \\
\hline & RM1001 - RM2500 & 27.5 & 72.5 & 51 & \\
\hline & RM2501 - RM4000 & 29.7 & 70.3 & 37 & \\
\hline & $\geq \mathrm{RM} 4001$ & 47.8 & 52.2 & 23 & \\
\hline \multirow[t]{2}{*}{ Job Category } & White Collar & 17.8 & 82.2 & 45 & \multirow[t]{2}{*}{$5.94^{* *}$} \\
\hline & Blue Collar & 39.0 & 61.0 & 77 & \\
\hline
\end{tabular}

Note: ${ }^{* * *} \mathrm{p}<0.01,{ }^{* *} \mathrm{p}<0.05$ and ${ }^{*} \mathrm{p}<0.1$

Differences in Complaint Behavior According to Psychographics between Complainers and Non-Complainers

In testing the second hypothesis, the t-test was carried out. Table 7 shows the t-test results for psychographic differences between complainers and non-complainers.

Table 7 shows that the mean scores of complainers and non-complainers differed according to their psychographics. The t-test 
results show significant levels, providing $(\mathrm{p}<0.01)$ evidence to support H2a to H2f. Thus, H2 was fully supported.

Differences in Complaint Behavior According to Attitude toward Businesses Between Complainers and Non-Complainers

In testing the third hypothesis, the t-test was again conducted. Table 8 shows the t-test results for differences between complainers and noncomplainers according to their attitude toward business.

Table 8 shows that the difference in mean scores for attitude toward businesses between complainers and non-complainers was significant $(p<0.05)$. This result provided support for H3.
Differences in Complaint Behavior According to Product Attributes between Complainers and Non-Complainers

In testing the fourth hypothesis, the t-test was undertaken. Table 9 shows the t-test result for the difference between complainers and noncomplainers according to their perception toward product attributes.

Table 9, shows that the difference in mean scores for product attributes between complainers and non-complainers was significant ( $\mathrm{p}<0.01$ ). This result provided support for $\mathrm{H} 4$.

Determining Variables That Discriminate Between Complainers and Non-Complainers Discriminant analysis was conducted to test whether the 15 variables can help to discriminate

\section{Table 7}

T-Test Results for Psychographic Differences between Complainers and Non- Complainers

\begin{tabular}{lccc}
\hline Dimensions & Complainers & Non Complainers & t-value \\
\hline Self-confidence and individualism & 3.62 & 3.31 & $3.074^{* *}$ \\
Conservatism & 2.06 & 2.38 & $-2.893^{* *}$ \\
Assertiveness & 3.76 & 3.41 & $3.097^{* *}$ \\
Risk taking attitude & 3.69 & 3.09 & $5.474^{* *}$ \\
Attitude toward complaining & 3.60 & 3.04 & $4.218^{* *}$ \\
Sense of justice & 4.01 & 3.56 & $3.253^{* *}$ \\
\hline
\end{tabular}

$* * \mathrm{p}<0.01$

Table 8

T-test Results for Differences in Attitude toward Businesses between Complainers and Non-Complainers

\begin{tabular}{lccc}
\hline Variable & Complainers & Non Complainers & t-value \\
\hline Attitude Toward Businesses & 3.02 & 2.77 & $2.502 *$ \\
\hline$* \mathrm{p}<0.05$ & & & \\
\hline
\end{tabular}


Table 9

T-test Results for Differences in Perception Toward Product Attributes between Complainers and Non-Complainers

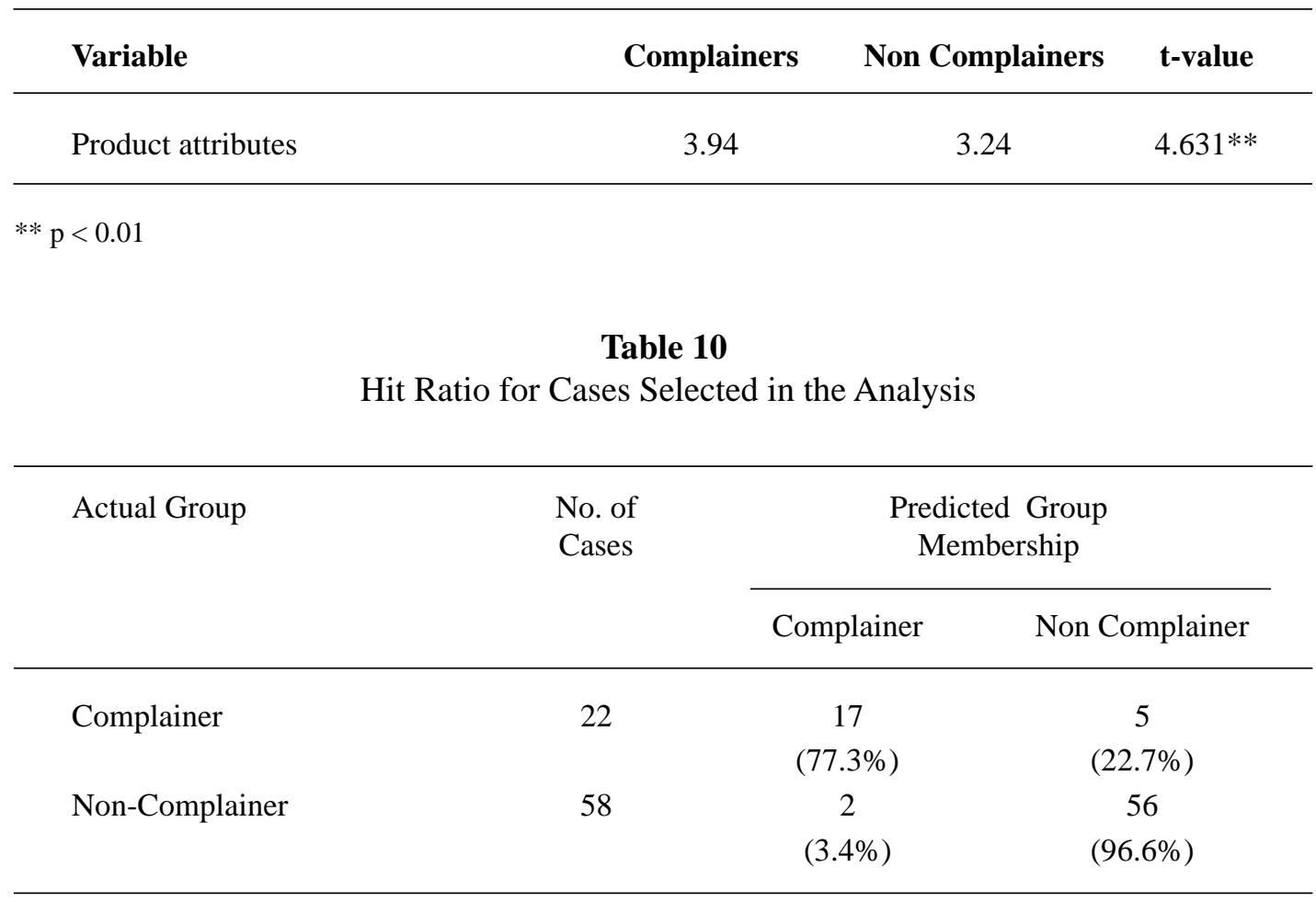

Percentage of "grouped" cases correctly classified: $91.3 \%$

Table 11

Hit Ratio for Cases in the Holdout Sample

\begin{tabular}{lccc}
\hline Actual Group & $\begin{array}{c}\text { No. of } \\
\text { Cases }\end{array}$ & \multicolumn{2}{c}{$\begin{array}{c}\text { Predicted Group } \\
\text { Membership }\end{array}$} \\
\cline { 3 - 4 } & & 12 & Non Complainer \\
\hline Complainer & 17 & $(70.6 \%)$ & 5 \\
Non-Complainer & 25 & 3 & $(29.4 \%)$ \\
& & $(12.0 \%)$ & 22 \\
& & $(88.0 \%)$ \\
\hline
\end{tabular}

Percentage of "grouped" cases correctly classified: $81.0 \%$ 
Table 12

Comparing the Goodness of Measure (Holdout Sample)

\begin{tabular}{lcc}
\hline Measure & Value & $\begin{array}{c}\text { Hit Ratio for Holdout } \\
\text { Sample }\end{array}$ \\
\hline Maximum Chance & $\begin{array}{c}81.0 \% \\
81.0 \%\end{array}$ \\
Proportional Chance & $60.13 \%$ & \\
\hline Comparison with Hair et al. (1998) & $75.17 \%$ \\
1.25 times higher than chance & \\
\hline Press Q Table Value & \multicolumn{2}{|c}{6.635} \\
Calculated Value & $16.1 * *$ \\
\hline
\end{tabular}

$* * \mathrm{p}<0.01$

complainers and non-complainers. The sample was randomly divided into two groups based on a 65-35 ratio with the first group as the analysis sample and the second group as the holdout sample. The analysis sample was used for estimation whereas the holdout sample was used for validation.

As shown in Tables 10 and 11, the predictive accuracy of the model for the analysis sample and holdout sample was $91.3 \%$ and $81.0 \%$ respectively. The results, suggest that the model, can be used to classify the respondents according to their complaint behavior, i.e. complainer or noncomplainer.

To examine whether the model was good and accurate, three tests were conducted as shown in Table 12. The table shows that the hit ratio exceeded both the maximum likelihood and proportional chance value. The Press' $Q$ statistics was significant $(\mathrm{P}<0.01)$. Therefore it can be concluded that the model developed is good and accurate. The overall hit ratio also exceeded the proportional chance criterion $(60.13 \%)$ by the requisite $25 \%$ cutoff (exceeded $75.17 \%$ ), giving support to the confidence in the predictive validity of the discriminant function and confirming the inferences made based on the univariate results.
(Hair, Anderson, Tatham, \& Black, 1998). This result further confirmed that the discriminant model is good and valid. Table 13 presents the summary of interpretive measures for the discriminant analysis.

Table 13 presents a summary of interpretive measures for the discriminant analysis. With a canonical correlation of 0.764 , and by squaring this value, it can be concluded that $58.4 \%$ of the variance in the dependent variable can be accounted for by this model. From the discriminant function loading, it can be concluded that self-confidence and individualism, conservatism, assertiveness, risk-taking attitude, attitude toward complaining, sense of justice and attitude towards businesses and education level were the factors that would help to discriminate a complainer from a non-complainer. The discriminant loadings of seven variables were positive in values. This indicates that complainers had higher self-confidence and individualism, assertiveness, risk-taking attitude, attitude toward complaining, sense of justice and attitude towards businesses whereas the negative value for conservatism indicates that the non complainers were higher on conservatism. The negative value obtained for education level of SPM/STPM indicates that those holding that qualification were mostly non-complainers. 
Table 13

Summary of Interpretive Measures for Discriminant Analysis

\begin{tabular}{|c|c|c|}
\hline Independent Variable & $\begin{array}{l}\text { Discriminant } \\
\text { Loading }\end{array}$ & Univariate F Ratio \\
\hline Self-confidence and individualism & 0.204 & $4.543 *$ \\
\hline Conservatism & -0.199 & $4.326^{*}$ \\
\hline Assertiveness & 0.245 & $6.541 *$ \\
\hline Risk-taking attitude & 0.536 & $31.398 * *$ \\
\hline Attitude toward complaining & 0.452 & $22.309 * *$ \\
\hline Sense of justice & 0.218 & $5.211^{*}$ \\
\hline Attitude towards businesses & 0.191 & $3.970 *$ \\
\hline Product attribute & 0.304 & $10.083 * *$ \\
\hline Male $($ Female $=0)$ & 0.166 & 3.031 \\
\hline Single (Married $=0$ ) & -0.109 & 1.310 \\
\hline Malay (Others $=0$ ) & -0.004 & 0.001 \\
\hline Chinese & -0.039 & 0.163 \\
\hline Indian & 0.053 & 0.308 \\
\hline $5-24($ Above $39=0)$ & -0.058 & 0.374 \\
\hline $25-29$ & 0.003 & 0.001 \\
\hline $30-34$ & 0.037 & 0.147 \\
\hline $35-39$ & 0.039 & 0.169 \\
\hline SPM/STPM $($ Degree and above $=0)$ & -0.219 & $5.267 *$ \\
\hline Certificate/Diploma & -0.082 & 0.741 \\
\hline RM 1000 and less (More than RM $6000=0$ ) & -0.078 & 0.661 \\
\hline RM 1000 - RM 2500 & -0.025 & 0.071 \\
\hline RM 2501 - RM 4000 & -0.035 & 0.132 \\
\hline RM 4001 - RM 6000 & 0.114 & 1.411 \\
\hline White Collar (Blue Collar =0) & -0.137 & 2.049 \\
\hline Group Centroid for Complainers & \multicolumn{2}{|r|}{1.899} \\
\hline Group Centroid for Non Complainers & \multicolumn{2}{|r|}{-0.720} \\
\hline Wilks Lambda & \multicolumn{2}{|r|}{0.416} \\
\hline P-value & \multicolumn{2}{|r|}{0.000} \\
\hline Canonical squared correlation & \multicolumn{2}{|r|}{0.764} \\
\hline
\end{tabular}

$* * \mathrm{p}<0.01 ; * \mathrm{p}<0.05$

\section{CONCLUSION}

The objective of this study is to examine whether consumers' complaint behavior varies according to demographics, psychographics, and attitudes. The t-test results show that consumers' complaint behavior varies according to gender, education level, marital status, and job profession. These findings are consistent with those of prior research (for instance, Moyer, 1985; Bettina et al., 1991, Kolodinsky, 1993; Keng et al., 1995; Hansen \& Woolridge, 2002; Phau \& Sari, 2004). Specifically, male, married, higher educated (degree or higher), and white-collared consumers are more likely to 
be complainers. Complaint behavior does not differ by ethnicity, age, and income level. One plausible reason may be attributed to the Malaysian cultural values of humility (Abdullah et al., 1992) where people regardless of ethnicity, age, and income level are more inclined to be nonassertive. Hence, Malaysians are less likely to complain even when they are dissatisfied with a product. Similarly, consumers' complaint behavior was found to vary according to their psychographics (for example, self-confidence and individualism, conservatism, assertiveness, risktaking orientation, and sense of justice). These findings are corroborated by those of past scholars (Allison, 1978; Morganosky \& Buckley, 1986; Bearden \& Mason, 1984; Richins, 1987; Blodgett et al., 1995; Keng et al., 1995, Phau \& Sari, 2004). Consumers who are more assertive, more confident and individualistic, more assertive, and possess a positive attitude toward complaining, are more likely to be complainers. On the other hand, individuals who are more conservative are less inclined to complain, which is consistent with the findings of Keng et al. (1995). Consumers' complaint behavior was also found to vary according to their attitudes towards businesses. Such finding is consistent with those of Singh's (1990) and Kolodinsky's (1993). In addition, complaint behavior differs according to product attributes. This finding is consistent with those of Richin's (1987). For instance, consumers are more likely to complain when they are dissatisfied with higher priced products.

From the practical point of view, manufacturing firms and sellers should pay special attention to the needs of consumers who are males, married, and better educated, hold white-collar jobs, are confident, and assertive, possess a positive attitude towards business, and perceive the product to be valuable. This group of consumers are more likely to be complainers when they are dissatisfied with a particular product by opting for public actions. Therefore, it is imperative for manufacturers and sellers to deal with their customers' complaints quickly and properly. When consumers feel that their problems have been resolved, they will be satisfied, and subsequently convey positive word-of-mouth about the company or seller to other customers or potential customers. This action, in turn, helps build customers' retention and loyalty. In additional, non-complainers should be considered as important as complainers. This is based on the fact that they prefer to warn their families and friends about their bad purchase experience (68\%) as shown by the results in this study. Given the disadvantages of negative word-of-mouth, companies should encourage consumers to voice their dissatisfaction by facilitating the complaint handling process.

Two major limitations worth noting in this investigation relate to the sample size and the product involved. Since this study is confined to consumers working in the Northern region of Malaysia, generalizability of the findings may be rather limited. Future researchers may need to focus on consumers in other regions as well to be able to gain a more comprehensive perspective. Second, this research covers complaints regarding durable products alone. In future, it may be worthwhile for future researchers to investigate complaint behaviors relating to other categories of products.

\section{REFERENCES}

Abdullah, A., Singh, S., \& Beng, O. S. (1992). Communicating with Malaysians. In A. Abdullah, Understanding the Malaysian Workforce: Guidelines for Managers (20-31). Kuala Lumpur: Malaysian Institute of Management.

Allison, N. K. (1978). A psychometric development of a test for consumer alienation from the marketplace. Journal of Marketing Research, 15, 565-575.

Bearden, W. O. \& Mason, J. B. (1984). An investigation of influences on consumer complaint reports. In T. C. Kinnear (Ed.), Advances in Consumer Research, (11). Utah: Association for Consumer Research.

Bearden, W. O. \& Teel, J. E. (1983). Selected determinants of consumer satisfaction 
and complaint reports. Journal of Marketing Research, 20, 21-28.

Bettina, T. C., Alan, D. B. \& Emin, B. (1991). Complaint behavior of MexicanAmerican consumers to a third party agency. Journal of Consumer Affairs, 25, $1-18$.

Bloch, P. H. \& Richins, M. L. (1983). A theoretical model for the study of product importance perceptions. Journal of Marketing, 47, 69-81.

Blodgett, J. G., Wakefield, K. L., \& Barnes, J. H. (1995). The effects of customer service on consumer complaining behavior. Journal of Services Marketing, 9, 31-42.

Cicarelli, J. (1974). On income, race and consumer behavior. The American Journal of Economics and Sociology, 33, 243-247.

Consumer Association of Penang (CAP). (1994). How to complain and get results: CAP guide, Penang: Consumer Association of Penang.

Day, R. L. \& Landon, L. (1977). Toward a theory of consumer complaining behavior. In A. G. Woodside, J. N. Sheth, \& P. D. Bennett (Eds.), Foundation of Consumer and Industrial Buying Behavior, (425437), New York: McGraw-Hill.

Folkes, V., Koletsky, S., \& Graham, J., (1987). A field study of causal inferences and consumer reaction: The view from the airport. Journal of Consumer Research, $13,534-539$.

Federation of Malaysian Consumers Associations (FOMCA) (available at http:// www.fomca.org.my) (downloaded on December 28, 2004).

Hair, J. F., Jr., Anderson, R. E., Tatham, R. L., \& Black, W. C. (1998). Multivariate Data Analysis. (5 ${ }^{\text {th }}$ ed.), New Jersey: PrenticeHall, Inc.
Hirschman, A. O. (1970). Exit, Voice and Loyalty. Massachusetts: Harvard University Press.

Hansen, S. W., \& Woolridge, B. R. (2002). An empirical investigation of complaint behavior among church members. Journal of Consumer Satisfaction, Dissatisfaction and Complaining Behavior, 15, 33-50.

Kaynak, E., Kucukemiroglu, O., \& Odabasi, Y. (1992). Consumer complaint handling in an advanced developing country-An empirical investigation. Journal of Business Ethics, 11(11), 813-823.

Keng, K. A., Richmond, D. \& Han, S. (1995). Determinants of consumer complaint behavior: A study of Singapore consumers. Journal of International Consumer Marketing, 8, 59-69.

Kim, C., Kim, S., Im, S., \& Shin, A. C. (2003). The effect of attitude and perception on consumer complaint intentions. Journal of International Consumer Marketing, 20(4), 352-371.

Kolodinsky, J. (1993). Complaints, redress and subsequent purchases of medical services by dissatisfied consumers. Journal of Consumer Policy, 16, 193-214

Kolodinsky, J. (1995). Usefulness of economics in explaining consumer complaints. The Journal of Consumer Affairs, 29, 29-53.

Lewis, R. C. (1983). When guests complain. Cornell Hotel and Restaurant Administration Quarterly, 24, 2, 23-32.

Morganosky, M. A. \& Buckley, H. M. (1986). Complaint behavior: Analysis by demographics, lifestyle and consumer values. Advances in Consumer Research, 14,223-226. 
Moyer, M. S. (1985). Characteristics of consumer complaints: Implication for marketing and public policy. Journal of Public Policy and Marketing, 3, 67-84.

Nunnally, J. C., \& Bernstein, I. H. (1994). Psychometric Theory. New York: McGraw-Hill.

Nyer, P. U. (2000). An Investigation into whether complaining can cause increased consumer satisfaction. Journal of Consumer Marketing, 17, 9-19.

Oliver, R. (1980). A cognitive model of the antecedents and consequences of satisfaction decisions. Journal of Marketing Research, 17, 460-469.

Oster, S. (1980). The determination of consumer complaints. Review of Economics and Statistics, 62, 603-609.

Phau, I., \& Sari, R. P. (2004). Engaging in complaint behavior: An Indonesian perspective, Marketing Intelligence \& Planning, 22(4), 407-426.

- Richins, M. L. (1981). An investigation of consumer's attitude toward complaining, Advances in Consumer Research, 9, 502506

Richins, M. L. (1983). Negative word of mouth by dissatisfied consumers: A pilot study. Journal of Marketing, 47, 68-78
Richins, M. L. (1987). A multivariate analysis of responses to dissatisfaction. Journal of the Academy of Marketing Science, 15, 4-31.

Singh, J. (1990). A typology of consumer dissatisfaction response styles. Journal of Retailing, 66, 57-99.

Tax, S. S., Brown, S. W., \& Chandrashekaran, M. (1998). Customers' evaluations of service complaint experiences: Implications for relationship marketing. Journal of Marketing, 62, 60-76.

Vijian, P. (2001). New Groups helping to air grouses, The Sun, June 24, 2001.

Watkins, H. S. \& Liu, R. (1996). Collectivism, individualism, and group membership: Implications for consumer complaining behaviors in multicultural contexts. Journal of International Consumer Marketing, 8, 69-85.

Warland, R. H., Herman, R. O. \& Willits, J. (1975). Dissatisfied consumers: Who gets upset and who takes action? Journal of Consumer Affairs, 9, 148-163

Williams, T. D., Drake, M. F., \& Moran, J., III. (1993). Complaint behavior, price and the patronized. International Journal of Retail \& Distribution Management, 21(5), 3-9. 